\title{
Kunnskapsformidling i handlingsplanens regi
}

Ved Mette Ystgaard og Anne Skumsnes

\section{Kunnskapsformidling står sentralt $i$ Handlingsplan mot selvmord. For å nå handlingsplanens} mål, er det ikke tilstrekkelig å sette $i$ gang forebyggende tiltak, modellfors $ø k$ og -forskning. Parallelt må kunnskap som allerede finnes, og den som utvikles $i$ prosjektperioden, formidles til alle som møter selvmordsproblematikken $i$ sin praktiske hverdag. Vi vil her giøre rede for hvordan arbeidet med kunnskapsformidling $i$ regi av handlingsplanen har vært lagt opp, hvor vi står $i$ dag og hva vi tenker om arbeidet fremover.

\section{Nodvendig med strategisk satsning}

Handlingsplanens virkeområde omfatter hovedsakelig sekundærforebyggende arbeid. Dette innebærer at tiltakene i planen retter seg alt vesentlig mot dem som står i fare for å ta sitt liv, og deres hjelpere. Arbeidet med kunnskapsformidling er også preget av dette. Målgruppene er først og fremst fagpersoner som mest sannsynlig ville komme til å spille en rolle i et selvmordstruet menneskes liv. Men selv med en slik avgrensning er formidlingsoppgaven svært stor og sammensatt. Hva slags kunnskap er relevant for ulike faggrupper? Hvilken kunnskap trenger for eksempel sykepleiere i eldreomsorgen, klinikere som har ansvar for pasienter $i$ akutt selvmordsfare, eller lærere, politi og sosialarbeidere som kan møte selvmordstruede i sin arbeidshver-

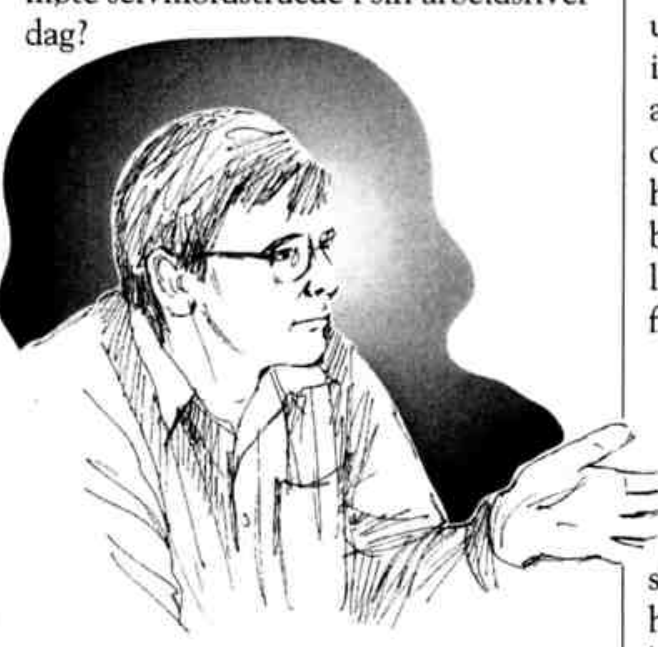

På hvilken måte skal vi nå frem med relevant kunnskap til de ulike faggruppene? Og ikke minst, hvordan kan handlingsplanens ressurser brukes mest mulig effektivt i dette arbeidet?

Det ble tidlig klart at det var nødvendig å satse bevisst på noen sentrale formid. lingsoppgaver som i sin tur kunne skape ringvirkninger.

\section{Den forste fasen}

I handlingsplanens første fase var det to arbeidsoppgaver som pekte seg ut. For det første var det viktig at den kunnskapen som allerede forelå på fagfeltet, ble tilgjengelig for så mange som mulig. Dette kunne heve kompetansen generelt i fagmiljøene og stimulere til økt forskningsog prosjektaktivitet. Ved Seksjon for selvmordsforskning og -forebygging ved Universitetet i Oslo, som er et nasjonalt kompetansesenter, så man dette som en viktig oppgave. Både dette tidsskriftet og senterets Internett-sider har vært sentrale satsninger på dette området.

Til høsten vil det også foreligge en lærebok "Tilbake til livet" redigert av senterets leder Lars Mehlum. Her blir alle sider ved selvmordsforebyggende arbeid belyst $i$ kapitler som er skrevet av fagfolk med særlig kompetanse på de ulike feltene innen suicidologi. $\mathrm{Vi}$ vil ikke her gå nærmere inn på senterets arbeid med tidsskriftet, Internett-sidene og læreboka. Poenget i denne sammenheng er å understreke betydningen av å bygge opp en slik grunnmur av tilgjengelig kunnskap, som forskjellige lokale formidlingstiltak kan benytte seg av.

Den andre oppgaven var å sørge for at de som var direkte engasjert $i$ forebyggende arbeid $i$ handlingsplanens regi, fikk mer konkret opplæring og støtte. Som et ledd i dette har Statens helsetilsyn holdt årlige prosjektlederkonferanser hvor erfarne klinikere og forskere har bidratt med kunnskap av særlig relevans for de prosjektene som er i gang. Samtidig har universitetssentrene gitt spesielle tilbud i sin region. Umiddelbart etter at Seksjon for selvmordsforskning og -forebygging ved Universitetet i Oslo var etablert, ble det startet halvårlige temadager hvor alle aktive $\mathrm{i}$ forebyggingsfeltet $\mathrm{i}$ helseregion $1 \circ g 2$ kunne møtes. Her kunne man fă faglig påfyll og utveksle erfaringer. Tilsvarende forebyggingsfora er etter hvert startet ved de regionale sentrene i Bergen og Trondheim.

Regionssenteret i Troms $ø$ har valgt en annen modell. På grunn av store reiseavstander og mangel på fagfolk med spesialkompetanse vil de benytte prinsipper fra et opplegg som er utviklet i Calgary i Canada. Her satses det på et to-trinns opplæringsprogram. En mindre gruppe fagfolk får først en ukes grundig undervisning, for deretter å kunne drive opplæringsvirksomhet på sitt hjemsted. Denne modellen vil bli nærmere beskrevet $i$ et senere nummer.

\section{Undervisningssektoren}

Med de hittil nevnte tiltak i god gjenge var det neste satsningsområdet å få temaet inn $i$ aktuelle utdanninger. Først når en får temaet inn i rammeplanene for relevante utdanninger, kan vi håpe på en systematisk og vedvarende kunnskapsheving, også etter handlingsplanens utløp.

For å samordne arbeidet rettet mot undervisningssektoren, tok Helsetilsynet i 1997 initiativ til å etablere et samarbeidsforum med det nasjonale og de regionale sentrene. På det første møtet la Seksjon for selvmordsforskning og forebygging frem en beskrivelse av status for arbeidet på dette området og et forslag til videre planer for kompetanseoppbygging. Dette forslaget ble retningsgivende for den videre arbeids- og ansvarsfordeling på dette feltet. Modellen som ble lagt frem (neste side), gir en oversikt over hvilke utdanninger som handlingsplanen i først omgang ville konsentrere seg om. Nederst har vi den største gruppen, som består av landets høgskoler 
med 30 deltakere fra høgskolene i helseregion 1 og 2. Det er også sendt brev til høgskolenes rektorer med oppfordring om å ta emnet inn i undervisningen.

\section{Grunn-, videre- og etterutdanning pà universitetsnivà}

Arbeidet rettet mot undervisningen ved universitetene har hatt et annet forløp. Som en del av Det medisinske fakultet har ansatte ved universitetssentrene bidratt regelmessig med 2 timers forelesning ved grunnutdanningen i medisin og på spesialistkurs i suicidologi i legers videre- og etterutdanning. Som utgangspunkt for å legge en mer offensiv plan, ble det høsten 1997 foretatt en kartlegging av hvilken undervisning som pr i dag foregår ved grunn-, videre- og etterutdanning for leger, psykologer og andre aktuelle universitetsfag. Denne oversikten viste at det skjedde lite undervisning i suicidologi ut over den undervisningen som de fire sentrene selv ga. Det som skjer av undervisning i suicidologi $\mathrm{i}$ andre fag enn medisin, er sporadiske tilbud, hovedsakelig basert på personlig engasjement og interesser. På bakgrunn av denne oversikten samarbeider nå regionssentrene og det nasjonale kompetansesenteret (Seksjon for selvmordsforskning og -forebygging) om en mer systematisk og samlet tilnærming til undervisning i suicidologi innen de sentrale universitetsfagene. Målet er å utarbeide forslag til et felles kjernepensum og ta dette opp med de aktuelle fakulteter, slik at man kan få i gang regelmessig undervisning.

\section{Noen tanker om videre arbeid}

Seksjon for selvmordsforskning og -forebygging så tidlig et behov for et mer systematisk og omfattende tverrfaglig utdanningstilbud til personer som har et særlig ansvar for utvikling og koordinering av forebyggende arbeid i fylker og kommuner. Idéen om en egen utdanning i suicidologi er nevnt tidligere. Seksjonen tenker seg dette som et 2-årig deltids/ utdanningsopplegg, med ukekurs hvert halvår, definert pensum og oppgaveskriving. Nærmere konkretisering av et slikt tilbud forutsetter et lengre tidsperspektiv enn handlingsplanens funksjonstid, men peker mot spennende utfordringer på litt lengre sikt.

Det samme gjør utvikling av undervisningstilbud $i$ et primærforebyggende perspektiv. Selv om handlingsplanen i først omgang retter seg mot høyrisikogrupper, er det viktig etter hvert å også satse mer systematisk i det primærforebyggende arbeidet. Dette forutsetter undervisningsopplegg rettet mot andre målgrupper og med et annet innhold. Handlingsplanen har allerede finansiert to undervisningsopplegg med et primærforebyggende siktemål. Begge oppleggene: "Kriser og mestring" (Hoel 1995) og videoen "To historier om livsvilje" (Jore 1996) med tilhørende elevhefte (Alveberg $\mathrm{m}$ fl 1998) og lærerhefte (Alveberg $\mathrm{m}$ fl 1998), retter seg mot ungdom i videregående skole. Det er vårt håp at det blir utviklet flere slike tilbud rettet mot ulike arenaer og målgrupper $\mathrm{i}$ årene som kommer.

\section{Referanser:}

Alveberg L, Andersen LK, Jægtvik T. "to historier om livsvilje": elevhefte. Arendal: Media Service, 1998.

Alveberg L, Andersen LK, Jægtvik T. "to historier om livsvilje": lærerhefte. Arendal: Media Service, 1998.

Brudal L. Dødsbevissthet. Om å velge livet eller døden. Oslo: Universitetsforlaget, 1998.

Brudal L, Skumsnes A. Samtaler i grenseland. Temahefte til essay om dødsbevissthet. Oslo: Universitetsforlaget, 1998.

Haukø W, Ystgaard M. Ả forstå og forklare selvmordsatferd. Skriftserie (IK-2613). Oslo : Statens helsetilsyn, 1998.

Hoel A. Kriser og mestring. Et undervisningsopplegg om ungdom $i$ utvikling. Fylkeslegen i Sør-Trøndelag, 1995.

Jore JR. To historier om livsvilje. Video. Arendal: Media Service, 1996.

Mehlum L. Tilbake til livet.

Oslo: Kunnskapsforlaget. Kommer høsten 1998.

Prosjektplan og handlingsplan mot selvmord 1994-1998. Skriftserie 4-95. Oslo.

Statens helsetilsyn, 1995.

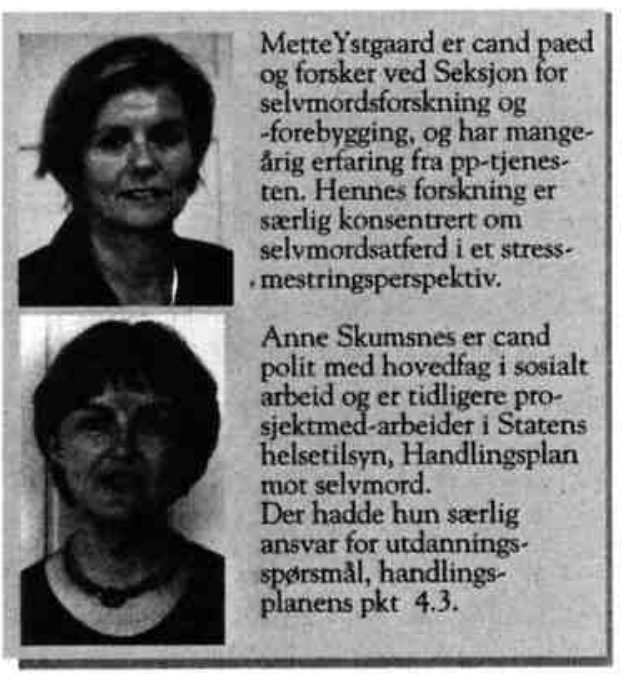

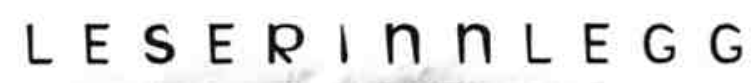

Redaksjonen oppfordyer leserne

til å komme med korte leserinnlegg.

De kan sendes via e-post til

kirsti.amundsen@psykiatri.uio.no

\section{To rapporter om selvmordsforebygging}

I Molde er det avsluttet to prosjekter innen selvmordsforebygging, og det foreligger to rapporter utarbeidet av prosjektleder Kirsti Foss. Rapportene kan bestilles fra Kirsti Foss, Familievernkontoret i Molde, Strandgt. 3, 6400 Molde, eller fra Seksjon for selvmordsforskning og -forebygging. Nærmere omtale av prosjektene vil komme i et senere nummer av Nytt i suicidologi.

Foss, Kirsti

Moldemodellen. Organisering av mottak, behandling og tiltakskjede i sykehus etter selvmordsfors $\phi \mathrm{k}$.

Molde: Fylkessjukehuset i Molde 1996. - 25 s. +7 vedlegg

Foss, Kirsti

Familievern. Selvmordsforebygging.

Molde: Familievernkontoret i Molde 1998, - 19 s. + 5 vedlegg 